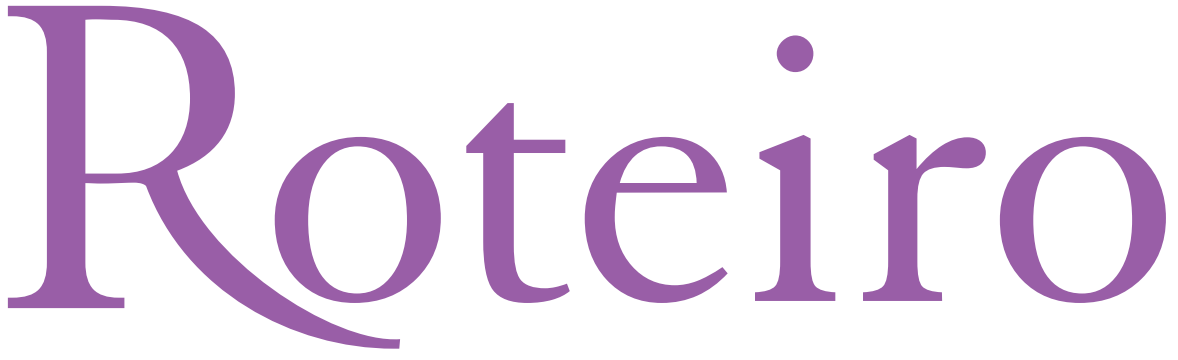

v. 43 n. 2 maio/ago. 2018

Agosto 2018

E-ISSN 2177-6059

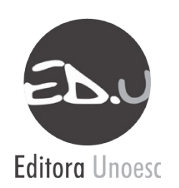

DOI desta edição: http://dx.doi.org/10.18593/r.v43i2

Indexação: Directory of Open Access Journals

IRESIE - Indice de Revistas de Educación Superior e Investigación Educativa

Sistema Regional de Información en Línea para Revistas Científicas de América Latina, el Caribe, España y Portugal (Latindex)

Academic Journals Database

Universidad de La Rioja, Proyecto Dialnet

Hemeroteca Latinoamericana (Hela)

Citas Latinoamericanas en Ciencias Sociales y Humanidades (Clase)

RCAAP - Repositório Científico de Acesso Aberto de Portugal

Portal de periódicos Capes

Educ@ - Fundação Carlos Chagas

Edubase

Sistema Eletrônico de Editoração de Revistas

INEP - Instituto Nacional de Estudos e Pesquisas Educacionais Anísio Teixeira

- Bibliografia Brasileira de Educação

Indexação Compartilhada de Artigos de Periódicos (ICAP)

Diadorim

Biblioteca do Conselho da Justiça Federal

Sumários.org - Sumários de Revistas Brasileiras 
É proibida a reprodução desta obra, de toda ou em parte, sob quaisquer formas ou por quaisquer meios, sem a permissão expressa da Editora.

Rua Getúlio Vargas, 2125, Bairro Flor da Serra, 89600-000 - Joaçaba - Santa Catarina, Brasil Fone: (55) (49) 3551-2065 - Fax: (55) (49)3551-2004 - editora@unoesc.edu.br

\section{Editora Unoesc}

Coordenação

Tiago de Matia

Revisão linguística e metodológica: Bianca Regina Paganini, Gilvana Toniélo, Giovana Patricia Bizinela

Revisão Eletrônica: Bianca Regina Paganini, Daniely Akemi Terao Guedes, Gilvana Toniélo

Projeto gráfico: Simone Dal Moro

Capa e diagramação: Simone Dal Moro

Dados Internacionais de Catalogação-na-Publicação (CIP)

R843 Roteiro / Universidade do Oeste de Santa Catarina. - v. 1, n. l

(jan./mar. 1978). - Joaçaba : Ed. Unoesc, 1978-

Quadrimestral 1978-1982/2016-; Semestral 1983-2015;

Publicado a partir do v. 17, n. 34 (1995) sob o título: Revista Roteiro

Modo de acesso: http://editora.unoesc.edu.br/index.php/roteiro

ISSN 0104-4311 - ISSN on-line 2177-6059

1. Educação - Periódicos I. Universidade do Oeste de Santa

Catarina.

Ficha catalográfica elaborada pela Biblioteca Universitária - Campus Joaçaba

\section{Editora-chefe}

Marilda Pasqual Schneider

roteiro@unoesc.edu.br

\section{Editor-adjunto}

Elton Luiz Nardi

Editor assistente

Nadiane Feldkercher

Priscila Monteiro Chaves

Editor associado nacional

Mônica Piccione Gomes Rios

Editor associado internacional

Ernesto Isunza Vera 


\section{Conselho Editorial Nacional}

Dr. Adolfo Ignacio Calderón, Pontifícia Universidade Católica de Campinas, Brasil

Dra. Adriana Fischer, Fundação Universidade Regional de Blumenau, Brasil

Dra. Alice Casimiro Lopes, Universidade do Estado do Rio de Janeiro, Brasil

Dr. Altair Alberto Fávero, Universidade de Passo Fundo, Brasil

Dra Amélia Kimiko Noma, Universidade Estadual de Maringá, Brasil

Dra. Anemari Roesler Luersen Vieira Lopes, Universidade Federal de Santa Maria, Brasil

Dra. Débora Raquel Alves Barreiros, Universidade do Estado do Rio de Janeiro, Brasil

Dra. Elisabete Monteiro de Aguiar, Universidade Estadual de Campinas, Brasil

Dra. Flávia Obino Corrêa Werle, Universidade do Vale do Rio dos Sinos, Brasil

Dr. José Camilo dos Santos Filho, Universidade Estadual de Campinas / Universidade do Oeste Paulista, Brasil

Dr. José Maria Baldino, Pontifícia Universidade Católica de Goiás, Brasil

Dr. Joviles Vitório Trevisol, Universidade Federal da Fronteira Sul, Brasil

Dra. Leda Scheibe, Universidade Federal de Santa Catarina, Brasil

Dra Maria de Fátima Barbosa Abdalla, Universidade Católica de Santos, Brasil

Dra. Maria de Lourdes Pinto Almeida, Universidade do Oeste de Santa Catarina, Brasil

Dra. Maria Isabel Moura Nascimento, Universidade Estadual de Ponta Grossa, Brasil

Dra. Nadia Aparecida de Souza, Universidade Estadual de Londrina, Brasil

Dr. Pablo Gentili, Universidade do Estado do Rio de Janeiro, Brasil

Dr. Paulo Sérgio de Almeida Correa, Universidade Federal do Pará, Brasil

Dra. Rosangela Célia Faustino, Universidade Estadual de Maringá, Brasil

Dra. Rosângela Gavioli Prieto, Universidade de São Paulo, Brasil

Dra. Rosanne Evangelista Dias, Universidade Federal do Rio de Janeiro, Brasil

Dra. Silvia Helena Andrade Brito, Universidade Federal de Mato Grosso do Sul, Brasil

Dra. Siomara Borba, Universidade do Estado do Rio de Janeiro, Brasil

Dra. Valéria Silva Ferreira, Universidade do Vale do Itajaí, Brasil

Dra. Zenilde Durli, Universidade Federal de Santa Catarina, Brasil

\section{Conselho Editorial Internacional}

Dr. Almerindo Janela Afonso, Universidade do Minho, Portugal

Dr. Aristeo Santos López, Universidad Autonoma del Estado de México, México

Dr. Bekisizwe S Ndimande, University of Texas at San Antonio, Estados Unidos da América

Dr. Enrique Martinez Larrechea, Instituto Universitario Claeh, Uruguai

Dr. Jaime Moreles Vázquez, Universidad de Colima, México

Dr. José Augusto de Brito Pacheco, Universidade do Minho, Portugal

Dr. José Carlos Morgado, Universidade do Minho, Portugal

Dr. José Maria Garcia Garduño, Universidad Autónoma de la Ciudad de México, México

Dr. Martín Omar Aveiro, Dirección de Educación Superior de Mendoza, Argentina

Dra. Maria de Lourdes Dionísio, Universidade do Minho, Portugal

Dra. Maria Fernanda dos Santos Martins, Universidade do Minho, Portugal

Dra. Maria Manuela Duarte Guilherme, Universidade de Coimbra, Portugal

Dra. María Verónica Leiva, Pontificia Universidad Católica de Valparaíso, Chile

Dra. Patricia Mata Benito, Universidad Nacional de Educación a Distancia, Espanha 


\section{FOCO E ESCOPO}

Vinculada ao Programa de Pós-Graduação em Educação da Universidade do Oeste de Santa Catarina, a Roteiro destina-se à divulgação de trabalhos acadêmico-científicos originais centrados nas políticas e nos processos educacionais.

\section{Missão}

Promover e socializar a produção de estudos e pesquisas acadêmico-científicos, de caráter teórico ou empírico, na área da educação.

\section{Categorias dos trabalhos}

Roteiro publica artigos, ensaios, resenhas de livro, entrevistas e outros produtos culturais de interesse para o campo educacional. Ainda organiza e aceita submissões de dossiês temáticos, com a finalidade de divulgar resultados de pesquisa e estudos científicos sobre temas relevantes e atuais da área da educação.

\section{FOCUS AND SCOPE}

Focus: Education

To promote and socialize the production of scientific knowledge.

\section{Mission:}

To promote and socialize the production of studies and scientific-academic researches, with theoretical or empirical characteristics, in the education area.

\section{Work Categories}

Roteiro publishes articles, testing, book reviews, interviews and other cultural products interesting to the educational field. It, yet, organizes thematic dossiers, with the purpose of disclosing results of researches and scientific studies about current issues. The call for thematic dossiers will attend to a specific notice. The issues of the dossier should establish debate around contemporary and relevant issues to the education area.

\section{PROCESSO DE AVALIAÇÃ̃}

Os originais serão submetidos à apreciação prévia do Conselho Editorial, que encaminhará aos pareceristas (no mínimo dois) aqueles que considerar adequados aos critérios editoriais do periódico, com a omissão do nome do autor e dos pareceristas durante o processo double blind review (o autor não sabe quem é o avaliador e este também desconhece quem é o autor). Cabe aos pareceristas recomendar a aceitação, recusar ou solicitar reformulação dos trabalhos submetidos. No caso de reformulação, os textos retornarão aos pareceristas para avaliação final.

Com dois pareceres favoráveis, o manuscrito será encaminhado ao Conselho Editorial para ad referendum e comunicação ao autor. Pequenas alterações no texto poderão ser efetuadas pelo Conselho Editorial, de acordo com critérios e normas operacionais internas.

A política editorial da Roteiro define as seguintes categorias para avaliação dos manuscritos: conteúdo, forma, originalidade, relevância, atualidade e adequação ao escopo editorial.

\section{EVALUATION PROCESS}

The originals will be submitted to the previous appraisal from the Editorial Commission, which will send to the referees (at least two), the ones that are considered appropriate to the periodical editorial criteria, omitting the author's and the referees' names during the double blind review process (the author does not know who the evaluator is and the evaluator does not know the author either). It is the referees' duty to recommend the acceptance, refuse or require reformulation of the submitted works. In case of reformulation, the texts will return to the referees to a final evaluation.

With two favorable opinions, the manuscript will be sent to the Editorial Counsel to ad referendum and communication with the author. Small alterations in the text may be done by the Editorial Commission, according to the criteria and intern operational rules.

Roteiro's editorial policy defines the following categories to the evaluation of the manuscripts: content, form, originality, relevance, newness and adequacy to the editorial scope. 


\section{Sumário}

\section{Editorial}

Marilda Pasqual Schneider, Nadiane Feldkercher, Priscila Monteiro Chaves

\section{APRESENTAÇÃO}

DOSSIÊ VIOLÊNCIA E EDUCAÇÃO

Mauricio João Farinon, Clenio Lago

\section{DOSSIE}

Violência sistêmica e educação

Systemic violence and education

Violencia sistémica y educación

Pedro Goergen

Violência da positividade e educação: da cultura do tédio à promoção da cultura do sentido.

The violence of positivity and education: from the culture of boredom to the promotion of the culture of meaning La violencia de la positividad y educación: de la cultura del tedio hacia la promoción de la cultura del sentido Altair Alberto Fávero

Johan Galtung e a violência escolar

Johan Galtung and school violence

Johan Galtung y la violencia escolar

Hans-Georg Flickinger 
Formação para a vida democrática em John Dewey: alternativa contra a violência humana e política

Education for democratic life in John Dewey: alternative against human and political violence

Formación para la vida democrática en John Dewey: alternativa contra la violencia humana y política

Claudio Almir Dalbosco

Violência, estética e educação: o caso do jovem Törless

Violence, aesthetics and education: the case of young Törless

Violencia, estética y educación: el caso del joven Törless

Nadja Hermann

A violência na escola de educação básica em diálogo reflexivo com Benjamin, Adorno e Rosa

Violence at the elementary school in reflective dialogue with Benjamin, Adorno and Rosa

La violencia en la escuela de educación básica en dialogo reflexivo con Benjamín, Adorno y Rosa

Bruno Pucci

Reflexões sobre educação, alteridade e violência a partir da concepção de constituição subjetiva em Levinas.

Reflections about education, alteration and violence from the conception of subjective constitution in Levinas

Reflexiones sobre educación, alteridad y violencia desde la concepción de constitución subjetiva en Levinas

Vanderlei Carbonara

Sombras de violência: premissas ocultas em epistemologias 527

Shadows of violence: premises hidden in epistemologies

Sombras de violencia: premisas ocultas en epistemologías

Roque Strieder, Clenio Lago 
Epistemologia da violência na educação no contexto da biopolítica contemporânea

Epistemology of violence in education in the context of contemporary biopolitics

Epistemología de la violencia en la educación en el contexto de la biopolítica contemporánea Amarildo Luiz Trevisan

Violencia política, derechos humanos y educación .583

Violência política, direitos humanos e educação

Political violence, human rights and education

Margarita Rosa Sgró

Violência, razão e cultura de paz 605

Violence, reason and culture of peace

Violencia, razón y cultura de paz

Paulo César Nodari

\section{RESENHA}

Topologia da violência: reflexões para pensar a sociedade contemporânea

Alcemira Maria Fávero

Camila Fávero

\section{ARTIGOS DE DEMANDA CONTÍNUA}

Disputas, negociações e tensões: sobre a emergência do Instituto de Educação de Belford Roxo, RJ

Disputes, negotiations and strains: the emergency of Instituto de Educação de Belford Roxo, RJ

Disputas, negociaciones y tensiones: sobre la emergencia del Instituto de Educación de Belford Roxo, RJ José Cláudio Sooma Silva, Andréa Miguel Abrantes Ferreira 
Interculturalidade crítica e educação popular em diálogo

Critical interculturalism and popular education in dialogue

Interculturalidad crítica y educación popular em diálogo

José Wnilson Figueiredo, Walter Frantz

Semeando entusiasmos: a Reforma Orestes Guimarães em Santa Catarina (1910-1918)

Sowing enthusiasm: the Orestes Guimarães Reform in Santa Catarina (1910-1918)

Sembrando entusiasmos: la Reforma Orestes Guimarães en Santa Catarina (1910-1918)

Vanessa Goes Denardi, Gladys Mary Ghizoni Teive

O ProEMI e o ensino médio em tempo integral no Brasil 727

ProEMI and full-time high school in Brazil

El ProEMI y la escuela secundaria de tiempo completo en Brasil

Andréa Giordanna Araujo da Silva

Políticas curriculares para o Ensino Médio nas escolas do campo no Brasil

Curricular policies for Secondary Education in rural schools in Brazil Políticas curriculares para la Enseñanza Media en las escuelas rurales en Brasil

Paoline Bresolin, Chaiane Bukowski, Roberto Rafael Dias da Silva

A obrigatoriedade da pré-escola no contexto das parcerias públicoprivadas

The requirement of the pre-school in the context of public-private partnerships La obligatoria de la pre-escuela en el contexto de las asociaciones público-privado

Flavia de Figueiredo de Lamare 


\section{ENTREVISTA}

Entrevista com o Professor Doutor Klaus Klattenhoff - Universidade

Carl von Ossietzky von Oldenburg - Alemanha Johann Friedrich

Herbart: pedagogia geral e inclusiva

Odair Neitzel

Diretrizes para Autores

Sobre a capa

Olinda Evangelista 
